\title{
An extensional mechanism of instability and failure in the walls of open pit mines
}

\author{
M.C. Bridges AMC Consultants Pty Ltd, Australia
}

\begin{abstract}
Evidence from studies of instability and failures in the walls of open pit mines and cuttings indicates a predominance of an extensional mechanism, comprising toppling, ravelling and creep-subsidence. This is interpreted to arise from relief and dilation when a pit wall is excavated, removing overburden and lateral confinement of the wall. Evidence does not support sliding and shear or shallow toppling mechanisms of instability or failure.
\end{abstract}

\section{Introduction}

\section{$1.1 \quad$ Purpose and scope}

This article deals with the mechanism of instability and failure in the walls of open pit mines and similar cuttings in rock materials. 'Mechanism' is regarded as the relationship between forces and displacements. Conclusions on the mechanism of instability and failure are based primarily on evidence from case studies that involved instability and failure. The case studies considered are in the public domain, principally published papers and articles, and information on the web, but the conclusions account for personal experience, where most cases are unpublished and confidential.

A recent informal article on the mechanism that is discussed here is on the Web (Bridges, 2005).

\subsection{Background on mechanisms}

One of the early published conclusions on the mechanism of failure in rock materials seems to have been based on the experience from cuttings for the Panama Canal (Becker, 1916; and Committee of the National Academy of Sciences, 1924). It concluded that failures occurred by sliding (shear) on a circular arc. That mechanism was based on the model for soils at the time.

Intensive studies were undertaken from the 1960s. Notable studies during the 1960s for open pit mines were those in the USA (Merrill, 1968; Broadbent, 1972) and Britain (Hoek, 1972). These were based on studies at mine sites and in laboratories. In Europe there were studies of cuttings for civil engineering projects, such as dam sites. Hoek (1972) concluded that four types of failure mechanisms were important for slopes in rock (Figure 1). Rotational failures occurred principally in soils and granular materials, without a pattern of geologic structures. Plane failure was regarded as uncommon, and then only a special case of a wedge failure. Wedge failure was regarded as the commonest type. Toppling was regarded as a special case, where columns of rock dip into a wall.

Coates (1967) and Coates and Yu (1978), from studies in Canada during the 1960s and 1970s, proposed an additional 'block flow' mechanism of failure (Figure 1) for rock conditions where the structural conditions do not favour plane shear sliding or are not sufficiently ductile to permit rotational sliding. In these circumstances, crushing of the rock occurs, which propagates through a rock mass, leading to a general breakdown and failure as a flow of broken rock (Figure 2).

In Australia, there were intensive studies of the stability of brown coal (Rosengren and Krehula, 1967; Gloe et al., 1971; Gloe et al., 1973) and black coal (Mallett, 1982) open pit walls during the 1960s and 1970s. 

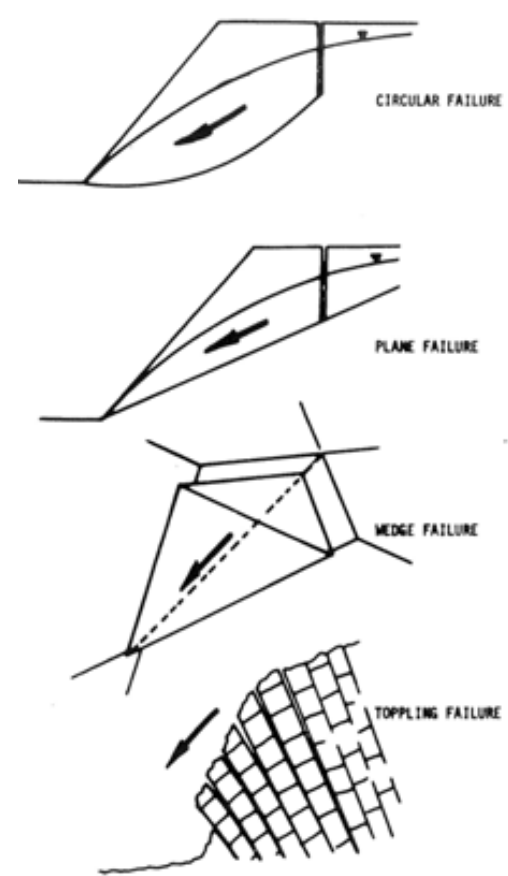

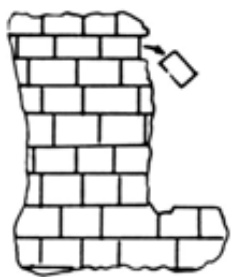

I ROCK FALL

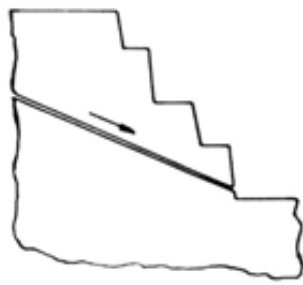

3 PLANE SHEAR

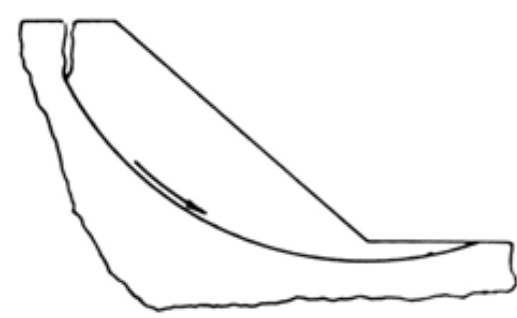

2 ROTATIONAL SHENR

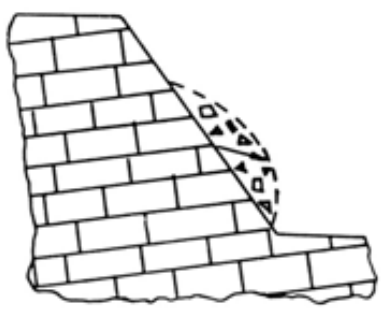

4 BLOCK rLOW

Figure 1 Mechanisms of failure of slopes that were proposed during the 1960s; (left) Hoek's four types of mechanisms (Hoek, 1972); (right) Coates' four types of mechanisms, which included 'block flow' (Coates, 1967)

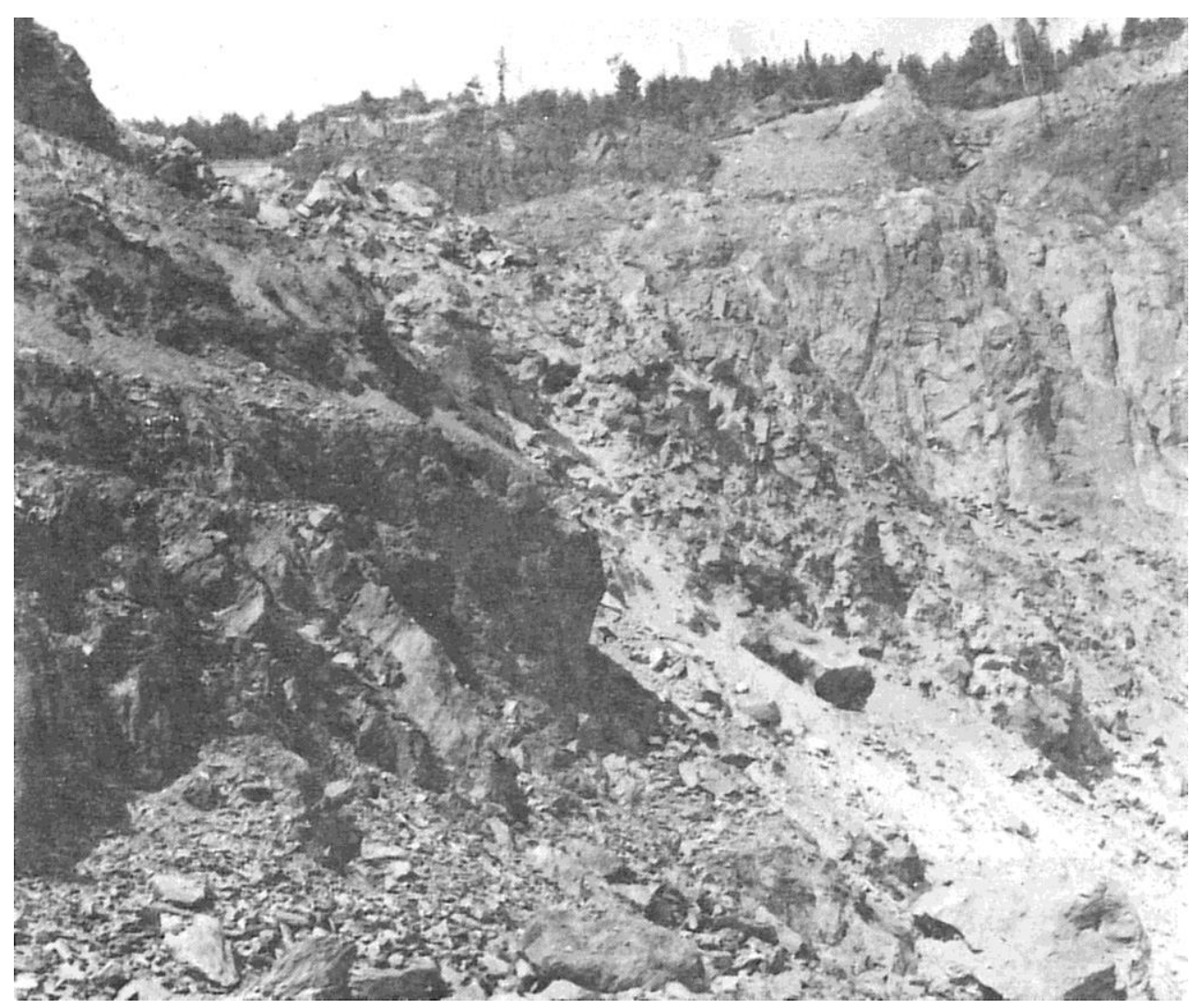

Figure 2 Instability and failure of a pit wall that was claimed to have failed by initiation by shearing at the toe followed by a breakdown of the rock mass (Coates and Yu, 1978) 


\section{$2 \quad$ Selected case studies}

\subsection{Chuquicamata open pit mine}

A portion of the southeast sector of the wall of the open pit failed in February 1969. The location, extent and timing of the failure had been predicted by observations and monitoring of displacements (Kennedy and Niemeyer, 1970, Voight and Kennedy, 1979). This became one of the famous case studies of failures of walls of open pits.

At the time of the failure the open pit was approximately $3.3 \mathrm{~km}$ long and $400 \mathrm{~m}$ deep. The pit was in a porphyry copper geologic setting, in the Chilean Andes.

In December 1967, extension cracks were observed to have opened at the crest of the pit wall. Instruments to measure displacements and seismic events were installed (Figure 3). Geologic structures were mapped. From January 1968, displacements across extension cracks were some millimetres per day. From April 1968, the top of the pit wall was 'unloaded', excavating about 4 million tonnes of rock, cutting down the crest of the pit wall by approximately $28 \mathrm{~m}$ (Figure 3 ).

Displacements increased during 1968. Contours of velocity of displacement across the pit wall defined a central zone of higher velocity and the edges of significant displacements. Velocities were related to mapped geological structures.

Since late 1967 and through 1968, the floor of the open pit was deepened by $39 \mathrm{~m}$ to accommodate an in-pit crusher. In November 1968 the rate of displacements increased after a blast for the crusher excavation broke about 406,000 tonnes. Rates of displacements first increased at the toe of the pit wall, then progressed up to the crest over time. Benches within the identified high-velocity zone broke-down. Operations on the haulage ramp were disrupted.

By 11 February 1969, velocities on the pit wall ranged up to $460 \mathrm{~mm}$ per day. Benches became hazardous and inaccessible. There were many small rockfalls. The frequency of seismic events increased. On 18 February 1969 at 6.58 pm, a part of the pit wall failed and collapsed. The collapse occurred over four minutes. Failure occurred over a height of $123 \mathrm{~m}$, involving an estimated 1.4 million tonnes of material. Most of the collapsed rock was from the zone where the highest velocities of displacement were previously identified. Another estimated 4.1 million tonnes of rock remained permanently 'deformed', with displacements up to $8 \mathrm{~m}$ (Figure 4).

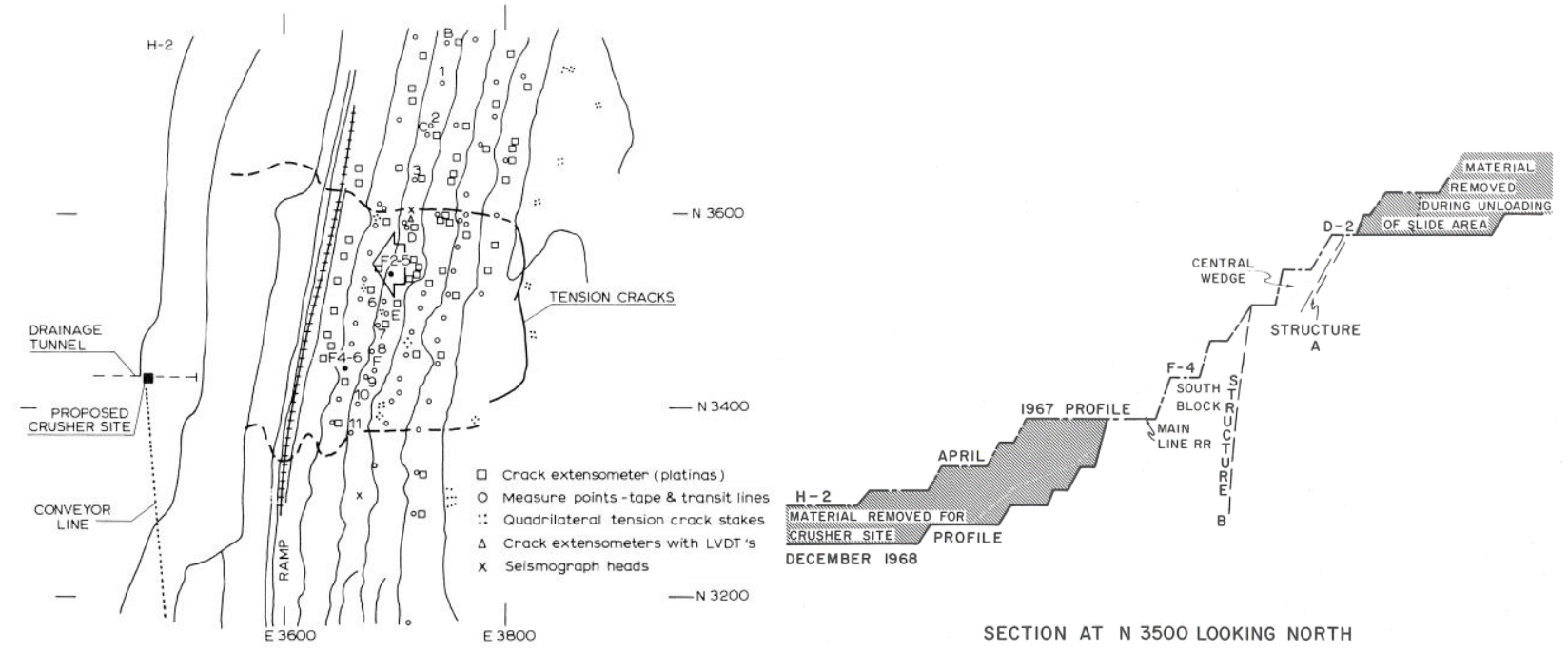

Figure 3 Plan (early 1968) and cross section (looking north) of the site of the failure and collapse in the southeastern sector of the Chuquicamata open pit in February 1969. Plan adapted from Voight and Kennedy (1979), section adapted from Kennedy and Niemeyer (1970) 


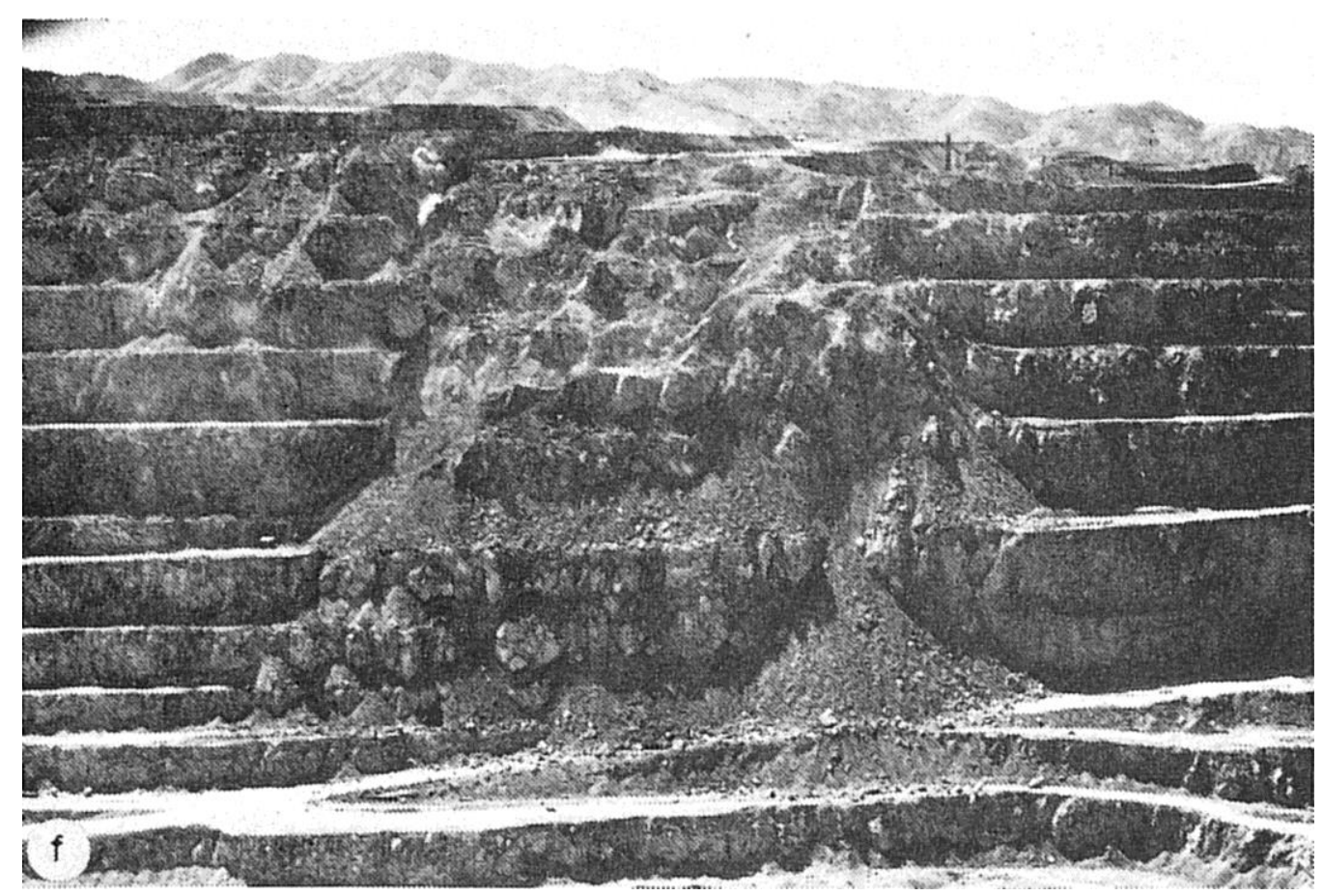

Figure 4 View of the Chuquicamata pit wall after the initial clean-up of the collapsed rock (from Voight and Kennedy, 1979)

\subsection{Afton open pit mine, Canada}

A large multi-bench failure occurred in the south wall of the Afton open pit in June 1986. The location and date of the failure was predicted and observed. The failure and prior developments were documented by Reid and Stewart (1986).

The pit was in a porphyry copper geological setting. The pit experienced freeze-thaw weather conditions.

By May 1985 (late Spring) monitoring instrumentation indicated that a section of the south rim of the pit was failing, extension cracks were evident on all underlying benches down to the haul ramp, near the bottom of the pit, at a depth of $170 \mathrm{~m}$ below the rim, over a length of about $335 \mathrm{~m}$ of the pit wall, and a bench-scale failure had occurred just above the haul ramp. Subsequently, two more bench-scale failures occurred in the same location above the haul ramp in August 1985 and March 1986.

Displacements within the pit wall continued. Overall, rates of displacement were $6 \mathrm{~mm}$ per day, but patches of stronger, intact rock were moving slower than patches of weaker fractured rock. An inclinometer near the crest indicated displacements to a depth of $24 \mathrm{~m}$. Observations and measurements indicated a toppling mechanism of failure.

In May 1986, three survey stations that lay directly up-slope from the previous bench-scale failures, showed accelerating rates of displacement. Further cracks developed in the upper haul road. By 5 June, rates of displacement reached $1.2 \mathrm{~m}$ per hour, and a large scale failure was judged to be imminent.

A major collapse began at $0300 \mathrm{hrs}$ on 6 June 1986, lasting approximately 45 minutes. The collapse was observed, but darkness limited detailed observations. Intact blocks of rock were seen to topple from the wall and then disintegrate. Collapsed rock formed a talus pile, covering the haul road. The total amount of cracked and collapsed rock was estimated to be 7.3 million tonnes, of which an estimated 3 million tonnes collapsed or moved a large amount. Steady displacements of remaining rock continued until August 1986.

Data from monitoring stations showed that the central section of the cracked rock in the pit wall up to the failure was moving at a higher rate than the adjacent rock (Figure 5(a)). The previous cluster of bench-scale failures lay at the toe of this zone. 


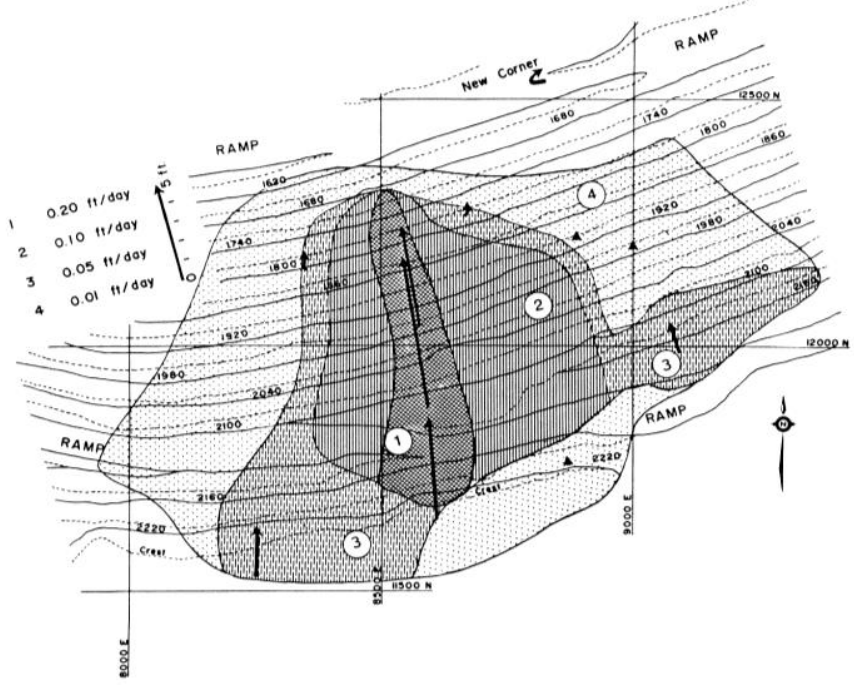

(a)

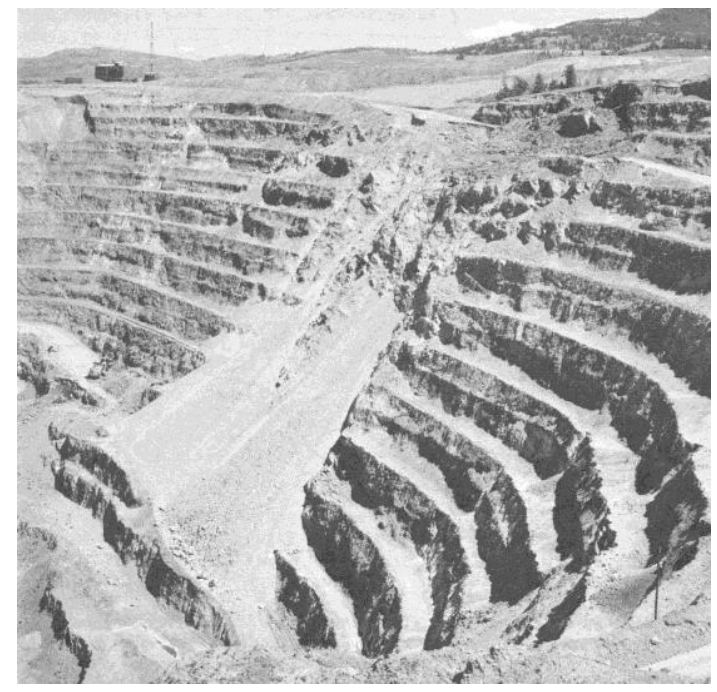

(b)

Figure 5 (a) Plan of the Afton pit wall where instability developed, showing zones of velocity of displacement that had developed prior to the failure of the pit wall (Reid and Stewart, 1986); and (b) view of the failure and collapse of the wall of the Afton open pit (Reid and Stewart, 1986)

\subsection{Other published case studies}

A number of published papers contribute to an understanding of the mechanics of open pit walls, including, from amongst many others: Brenda Mine (Calder and Blackwell, 1980; Blackwell and Calder, 1982), Tripp Mine (Miller, 1982), Highmont Mine (Newcomen and Martin, 1988), Muja Mine (Joass, 1993), Telfer Mine (Thompson and Cierlitza, 1993), Aznalcollar Mine (Hencher et al., 1996), Betze-Post Mine (Rose and Sharon, 2000; Sharon, 2001; Rose and Hungr, 2007), Highland Valley Lornex Mine (Newcomen and Shwydiuk, 2003), Chuquicamata (Calderon et al., 2003), Nchanga Mine (Naismith and Wessels, 2005; Wessels, 2009), Tom Price Iron Ore Mine (Day and Seery, 2007), Yallourn Mine (Victorian Government, 2008).

All of these papers include details of measurements and observations of failures in walls of open pit mines. They are only a selection - there are many other published examples.

\section{Common elements and special cases}

The range of case studies reported and known personally, include information that highlights a number of common elements within the process of yield, failure and collapse, regardless of the circumstances. These were evident in the two examples above.

\subsection{First signs of instability - extension cracks}

Typically, the first visible sign of a potential failure is the development of extension cracks (Figure 6). (These are frequently termed tension cracks, but 'tension' implies a known stress condition, whereas 'extension' is simply an observation).

The style of these cracks has a number of common elements. They preferentially develop at the ground surface behind a pit wall's crest, on haul ramps within a pit wall, and on benches within a wall (Figure 6). Their Initial opening is sub-horizontal, although there may be a slight downward component on the pit side. They tend to cluster in arcuate-shaped zones. These zones tend to be located near the mid-length of longer pit walls, although there are instances of locations near ends of walls. Within these zones, the trend of cracks-their strike-tend to be aligned with the strike of pervasive geological structures, such as bedding, foliation or veins, where they are present, and they strike at an acute angle to the pit wall (for example, Afton open pit). They have been reported to have developed out to many tens of metres, even to about 
$100 \mathrm{~m}$ and more behind a pit's crest at the ground surface. As well, there are reports of cracking, bulging, or distress being observed or measured in the vicinity of the toe of an eventual failure. An example of heave at the toe of a pit wall is shown in Figure 7.
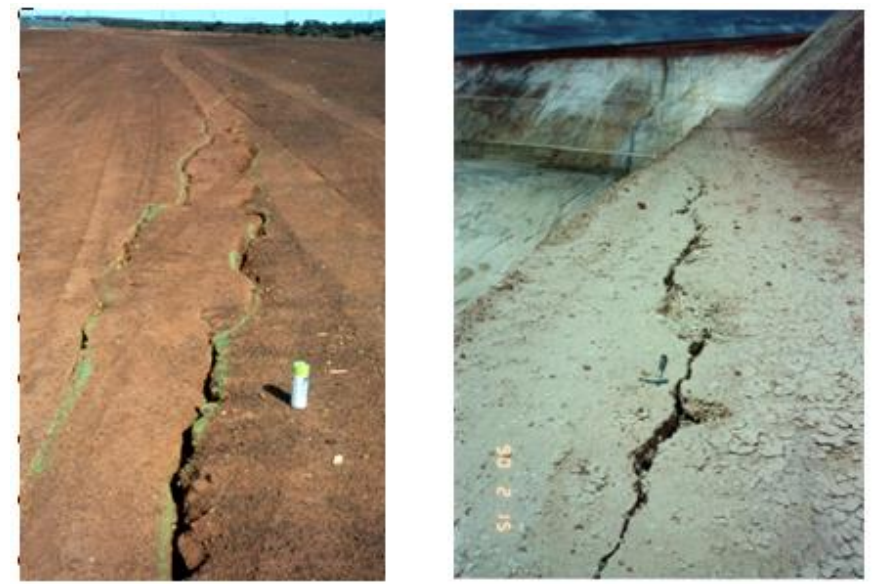

Figure 6 Extension cracks; (left) in the ground surface behind the crest of an open pit wall; (right) in a bench within a pit wall (photographs M.C. Bridges)

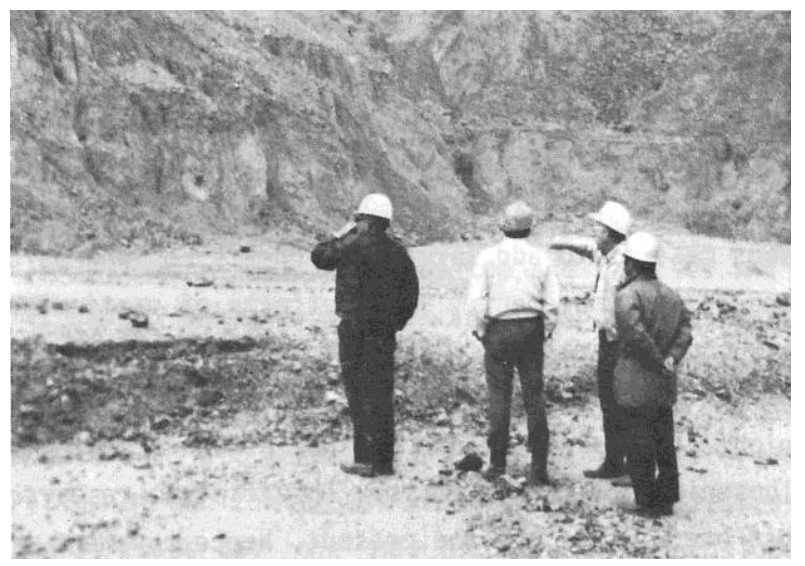

Figure 7 Heave of the floor of about $1 \mathrm{~m}$ near the toe of a $90 \mathrm{~m}$ high pit wall (from Coates and Yu, 1978)

Significant displacements occur in the wall and floor of open pits, responding to excavation of overburden and removal of lateral constraint, with no obvious consequential sign of instability. After introducing the mechanism of 'block flow', above, Coates and Yu (1978) added that 'another reaction of wall rock to excavation is deformation. The removal of ground releases stresses or pressures that were acting on the pit floor and wall faces before excavation. Removing these constraints results in a tendency for the floor to rise and for the walls to move inward.' Displacements in response to the cutback of the wall of the Kimbley experimental open pit were measured in each of two tunnels in the pit wall within and behind the cutback, shown in Figure 8. Upward vertical components of displacements near the cutback wall were approximately 3-10 mm. A detailed study of displacements with the Saxon clay pit, comprising a massive over consolidated clay (used for bricks), revealed significant displacements in the wall and toe-floor of the pit as pit walls were cut-back (Burland et al., 1977). At the Ok Tedi open pit mine, horizontal components of displacements of the pit wall to $400 \mathrm{~mm}$ over nearly three years were measured during a cut-back of the eastern wall (Baczynski, 2010). The crest of the Morwell open pit in brown coal displaced up to $1.9 \mathrm{~m}$ horizontally and subsided $1.1 \mathrm{~m}$ in response to excavation of the pit and associated drainage of groundwater from an underlying aquifer (Gloe et al., 1973). 


\subsection{Progression of instability - increasing displacements and ravelling (2)}

In some instances, instability continues to develop. Cracks continue to develop, and there is increasing displacement and progression of instability over larger areas of a pit wall. Small failures may develop over a pit wall, especially at the crests of batters.

At this stage, there tends to be a divergent style of instability for the various types of geological conditions, such as weak surficial sediments, weathered and altered rock materials, and strong unweathered or unaltered rock materials. Many common elements remain, though.

Displacements measured at the crest and upper areas of instability in a pit wall generally show a transition from principally sub-horizontal to down-slope. Displacements are greater at the crest than at the toe. Magnitudes and rates of displacements may be influenced by rainfall, dewatering of groundwater and progressive exposure of the underlying pit wall as benches are cut.

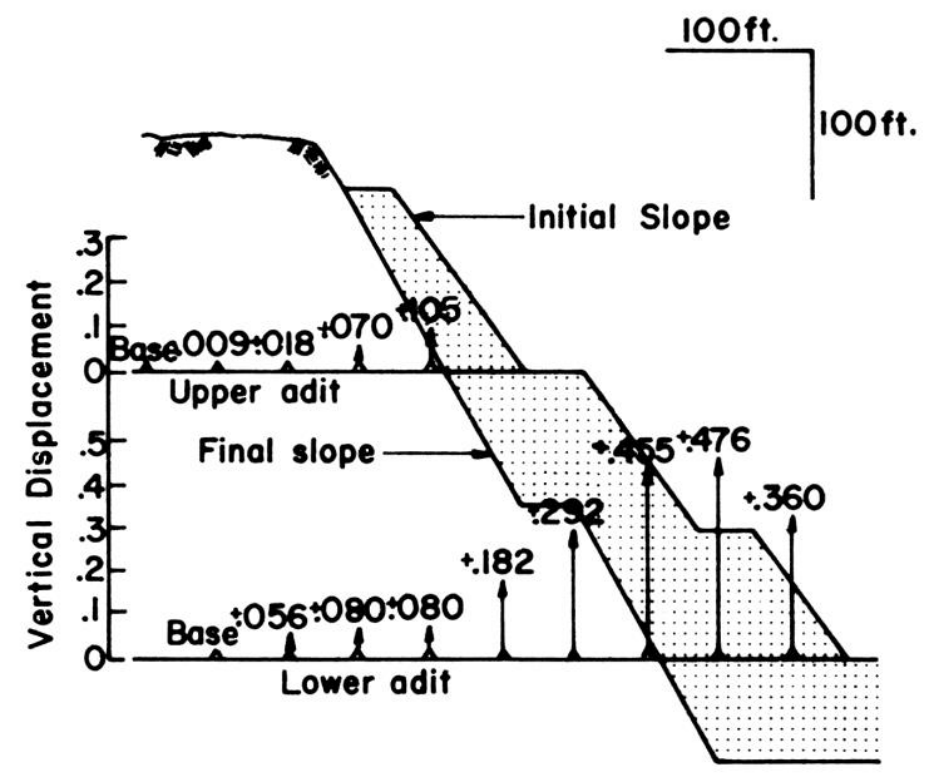

Figure 8 Representation of the vertical component of displacement measured in two adits in the wall of the Kimbley experimental open pit, in response to the shaded cutback of the pit wall. Values are in inches. Adapted from Broadbent (1972)

The combination of visible cracking and measured displacements show an overall outward rotation of the mass of unstable material. Especially the crest of a failure rotates outward from the pit wall (toward the pit). Measurements of displacements within an unstable pit wall, by tiltmeters for example, show an outward rotation of the unstable mass. This may be regarded as toppling.

Instability may progress over time, in response to down-cutting of the pit wall. Initial small scale ravelling or sloughing failures-mostly at a bench scale-may extend through the area of instability.

In some instances, typically in a weak rock material, a surficial zone of failed material may creep down-slope, more or less at a steady rate, with little or no visible sign of cracking or break-down.

Within a stronger rock mass, cracking tends to preferentially develop along natural fractures and faults, or other geologic structures. Dilation, displacements and ravelling may even be concentrated at one or more extensive geologic structures, particularly where they occur at an acute angle to a pit wall.

\subsection{Accelerating displacements, failure, and collapse}

A final progression to failure may take any of several different forms, but there are still common underlying elements. 
In some instances, creep-subsidence may continue. Rates of displacement may increase over time, although there may be periods of accelerating and steady displacement. Outwardly the overall bench configuration of a pit wall may be maintained, although there may be bench-scale ravelling. There may not even be an eventual collapse of the pit wall.

In other instances, an unstable pit wall may slump, breaking-down along cracks and geologic structures, but remaining recognisably intact and (meta) stable for a time (Figure I). This process may extend to a complete progressive breakdown of the failing mass, resulting in a scree pile against the pit wall (Figure 4).

Typically though, increasing rates of cracking and displacement lead to a final massive collapse of a pit wall (Figures 2, 5 and 6).

There are reports of observations of a few such failures, which was possible when a collapse was predicted from monitoring:

- "... blocks .... could be seen to topple and rapidly disintegrate" (Reid and Stewart, 1986).

- "Witnesses .... said the top of the east highwall leaned out toward the middle of the 4840 level and suddenly crumbled under the weight of the rock" (Grimes and Nowel, 1995).

- ".... large cracks were observed forming in the face at the eastern end. The failure occurred in 5 minutes ...." (Feltus, 1993).

- "Final collapse of the slope commenced ... with sloughing and collapse of benches... The main collapse followed ... and completely inundated the $330 \mathrm{~m}$ bench" (Naismith and Wessels, 2005).

The process of collapse is a progressive breakdown of wall rock. It can take minutes to part of an hour to stabilise. It is accompanied by a cloud of dust in some instances. A series of photographs of the failure of the Chuquicamata mine's pit wall in 1969 showed the breakdown - or rather the ensuing dust - of the collapsing mass.

\subsection{Low-angle pit walls}

Low angle pit walls are an exception to the usual typical range of slope angles for pit walls. A low-angle is defined as less than $37^{\circ}$, which is the typical rill slope angle for broken and collapsed rock.

There are a number of examples of unstable pit walls excavated at angles less than or about $37^{\circ}$.

Zavodni and McCarter (1977) described failures in the northwest sector of the Bingham Canyon Mine. By March 1966, the boundaries of instability were evident, including 'tension' fractures near the top and basal thrusting near the toe, over a height of $145 \mathrm{~m}$. Major slide movement occurred in 1967, over a height of $230 \mathrm{~m}$ and $60-150 \mathrm{~m}$ width. The average slope of the pit wall was $25-29^{\circ}$.

Sharp et al. (1987) described slopes in ultrabasic rocks at the Jeffrey Mine that had a history of major failures during $1970-1986$. Pit wall angles were $20-25^{\circ}$, over $300 \mathrm{~m}$ high walls. Instability was extensively monitored. Meaningful constitutive models of the behaviour of the rock mass could not be derived because of the complex nature of the ultrabasic rock. Groundwater had a major influence on instability.

Hutchison et al. (2000) and Coulthard et al. (1999) described 'flexural toppling' at the Savage River Mine. This form of instability had recurred in the western walls of pits since 1989. Pit wall slope angles were subsequently restricted to $37^{\circ}$. Western walls comprised mafic schists and mylonites, dipping $60-85^{\circ}$ into the wall. A feature of the deformation was 'reverse scarps', or obsequent faults.

A similar form of obsequent faults was described by Baczynski et al. (2008), but in a pit wall at a $45^{\circ}$ slope angle, in the Ok Tedi Mine. It was described as a toppling failure.

Cremeens et al. (2000) and Cremeens (2003) described instability in a part of a pit wall at a low slope angle.

Rapiman (1993) described instability in the western wall of the Chuquicamata Mine. Obsequent faults had developed. 


\subsection{Under-caving of pit walls}

There are a number of published examples of the effects on walls of open pits from subsidence induced by under-caving and underlying underground mining generally.

Graham (1989) described a failure of part of pit wall in the Vanderbijl Mine that was induced by underlying underground mining. The consequent deformation and failure of the pit wall was monitored and observed.

Undercutting of the completed Palabora open pit by an underlying block cave mine was described by Moss et al. (2006) and Brummer et al. (2006).

\section{Conclusions on the mechanism of failure}

\subsection{Opinions on the mechanism of failure}

The evidence from the case studies mentioned above, and many others, supports some form of extensional mechanics occurring with yield and failure of a pit wall. This runs counter to an apparent consensus that shear mechanisms are dominant, judged by numerous published papers and books, supported by commercial software. However, over the years, some eminent practitioners have challenged the consensus on a sliding/shear model of the mechanics of failure.

Hoek et al. (2000), presenting an invited paper at GeoEng 2000, noted that current analytical practices recognised two distinct categories: Structurally-controlled, kinematically possible failures, and non-structurally controlled, where some or all of the failure surface passes through a rock mass. They commented that these two categories were inadequate. Two examples, presented in the paper, illustrated the difficulties of the current models (Figure 9).

Simmons (2000), also at GeoEng 2000, put the case that "new rock mechanics models [are] needed for slope stability in open pit coal mines", because "... issues for pit [high-] walls may involve block fall, multi-block toppling, or composite material-defect mechanisms."

Read (2003), presenting the keynote paper at the (Australian) Fifth Large Open Pit Conference, concluded, in part, that "as the low stress environment of an open pit is created and the structured rock mass dilates, the individual particles or blocks of rock may be free to move apart and start moving about. Under these circumstances, the stability of the slope is potentially a function of particle interlock rather than particle friction."
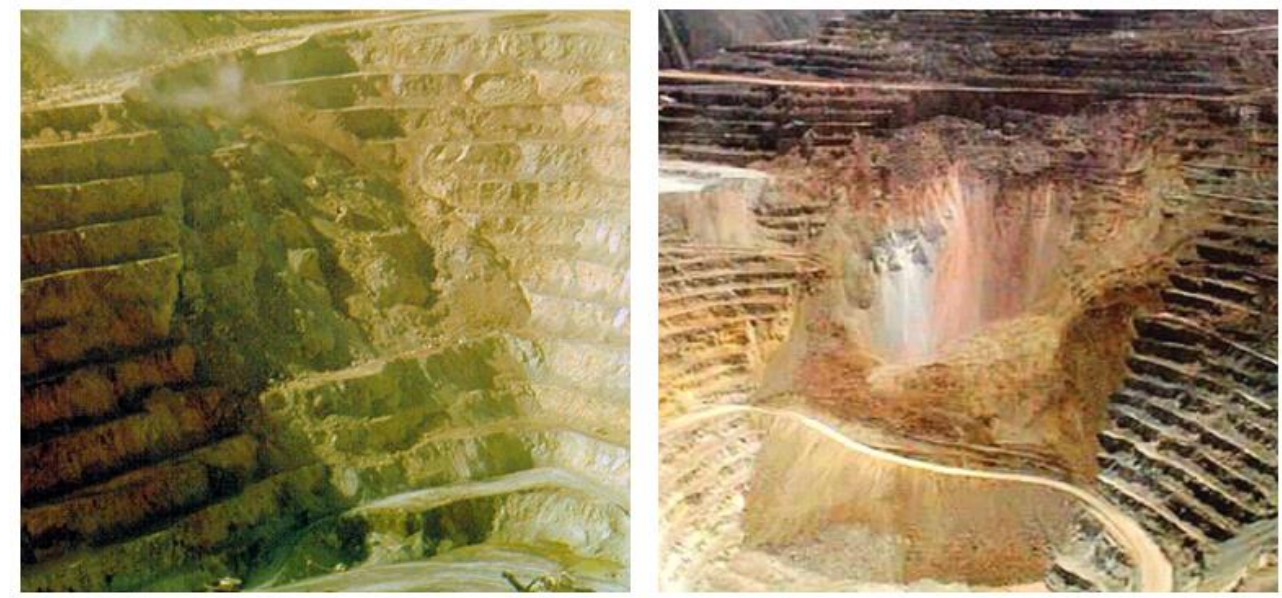

Figure 9 Large-scale failures in walls of open pits; (left) structural control by faults is evident at the top, but the mechanism in the lower part is unclear; (right) evidence of faults at the back of the failure, but the trigger of the failure was unclear (Hoek et al., 2000)

Stacey and Xianbin (2004) reported an examination of the occurrence of extension strain in open pit walls, concluding that "the greatest magnitudes of extension strain occur near the toe of the slope, either in the 
slope itself or in the floor ... and that the magnitudes of the strains are considered to be large enough to result in fracturing of intact rock ... adverse for slope stability." The study was based on numerical modelling.

\subsection{Proposed extensional mechanism}

Rock is complex and naturally variable. Walls of open pit mines are located adjacent to orebodies, rather than where the best rock conditions occur. Pit walls include weathered rock, groundwater, hydrothermally and metamorphically altered rock, swelling and degrading rock, sometimes in an environment of high rainfall and freeze-thaw. In these settings, the yield, failure and collapse of a pit wall is complex and variable from place to place. The mechanics of rock in this process are also complex and variable.

\subsubsection{Yield and dilation}

Primarily, yield and dilation in the wall of an open pit or a similar type of cutting involves extensional mechanics. Exposed rock dilates and cracks in response to the removal of overburden and lateral constraint as the wall is excavated. For most rock conditions, this is an irreversible process; it is not simply an elastic relief. The motive force is stored strain energy in the rock, with porewater pressure and dynamic forces (such as seismicity and blast vibration) added in some circumstances.

Relief, dilation and cracking begin from an early stage of excavation of a pit or cutting. This may be in weathered rock or overlying sediments, which have high deformability, and susceptible to relatively large dilation and cracking. Visible extension cracks may begin to develop. As a pit is cut down, the toe of the wall experiences a combination of lateral relief in the lower wall and uplift in the adjacent floor. This is manifested as bulging and heave in some cases, but typically is only measureable as small displacements.

This process is progressive as a wall is cut down. Effects of dilation and cracking at the toe of a wall is incorporated in the overlying wall when the next bench is cut. Yield and cracking is path-dependent.

For rock masses of high-strength materials and sparse fracturing there will be relatively low dilation and displacements, and no evident cracking. For others, there will be relatively high dilation and cracking, evident as open extension cracks, and possibly even some localised loosening or ravelling across a wall.

Evidence indicates that a greater amount and extent of cracking/displacements occur where there is a wide, flat surface at the top of a part of a wall, such as the ground surface, haul ramp, or step-out. Here, dilation and displacements have freedom across two surfaces, rather than just a face within a pit or cutting. For most situations, nothing more occurs. For others, yield and dilation progress to failure and collapse.

\subsubsection{Failure and collapse}

Failure and collapse is interpreted to occur where a wall is cut too steeply for the rock conditions. A wall that is too steep for the conditions is regarded as undercutting wall rock at the toe of the wall or base of particular rock conditions. It is regarded as analogous to undercutting a pit's wall by underlying caving, or stoping generally. Broadbent (1972) described how a part of the wall of the Kimbley open pit was deliberately undercut (by explosives) to precipitate an experimental collapse of the overlying wall. Exposed rock in an over-steepened pit wall responds in the same style as an undercut wall, as for the examples above.

As an over-steep pit wall is cut down, a greater amount of cracking and dilation occurs than if the wall were at a lesser slope angle. Underlying cracked and dilated rock cannot support overlying cracked and dilated rock. The loosened cracked mass subsides and creeps down-slope as excavation progresses. Upper parts of the moving mass rotate toward the pit, in the style of toppling, vectors of displacement turn to down-slope. Lower parts, especially at the toe, displace toward the pit, and may even have an upward component. The toe may show effects of bulging. As each bench is cut down, cumulative displacements and rates of displacements increase. Localised failures at a bench-scale occur. 
A stage is reached when excavation of another bench or some external influence, such as rainfall, precipitates accelerated displacements at the toe, leading to mass failure and collapse. Failure and collapse begin at the toe of a failure.

A failure surface develops where moving cracked and dilated rock kinks against the stable rock within the pit wall. This is an extensional mechanism, not a shear or sliding mechanism. Failed and collapsing rock slumps, runs, or rolls down the failure surface.

\subsubsection{Characteristics of failure and collapse}

There are variations of details of failure and collapse from one instance to another, depending on rock and geometric conditions. There are though some evident common elements amongst them.

Prior to a failure, amounts and rates of displacements at the top are greater than at the bottom; displacements at the top are down-slope, whereas those at the bottom are sub-horizontal; amounts and rates of displacements are greater at the centre, along the pit wall, than the edges where the failure occurs; amounts and rates of displacements are greater at the surface of a pit wall than deeper into the wall.

Rates of displacements and microseismic events increase exponentially during the weeks, days and hours before a failure. There may be increased visible cracking and ravelling across the wall. Breakup and collapse of the failing mass occur before the full failure surface has developed. A failure often generates a dust cloud.

Amounts and rates of displacements may be episodic prior to a failure. Each episode is characterised as initial accelerated displacements, followed by deceleration to a steady rate. Cutting of a lower bench at the toe of the pending failure is the usual trigger for each episode of accelerated displacements and the eventual failure. Increased porewater pressure (such as rainfall or flooding of a river) or external seismicity may be a trigger in some circumstances.

The resulting failure surface, to the degree that it can be seen and conclusions drawn, is a crudely arcuate shape in plan and section, but jagged and irregular. Its profile in section is typically steep to near-vertical at the top. Profiles at the base are less clear, but may range from arcuate to flat-bottomed.

The remaining pit wall behind a failure surface tends to stabilise after a failure and collapse. No further displacements occur behind a talus pile formed from a collapse. Blocks of failed but not collapsed rock tend to stabilise. Exposed head scarps, may crack and break-back, but usually of a lesser size than the preceding failure.

Extensive geologic structures in the pit wall, such as faults, dykes, thin sedimentary units, or rock contacts, may influence the location, style and extent of a failure. They may form surfaces of preferential dilation in the rock mass. The depth of relief, dilation, cracking and eventual failure into a pit wall may be shallower or deeper than it might be otherwise, depending on its nature and relative orientation. Such a structure may form a planar part of the eventual failure surface.

Tops or bottoms of failures may be limited or extend to wide, flat surfaces within a pit wall. Wide, flat surfaces, such as the ground surface, haul ramp or step-out, are interpreted to facilitate or exacerbate failures by providing two surfaces with freedom for dilation. On the other hand, the pit wall side of haul ramps and step-outs are interpreted to provide a buttress against the overlying pit wall, confining the bottoms of failures.

Failures occur within the weakest material in a pit wall; they generally do not occur in typical conditions. The weakest material or zone may include an extensive geologic structure, a zone of altered rock, a zone of high porewater pressure, or a particular rock unit. Some materials are more dilatant than those adjacent to them, such as ultramafics, coal, zones with retrogressed minerals (especially sericite, chlorite, talc), and supergene clays.

Porewater in cracks may have a major influence on dilation, cracking and failure, whether it be groundwater or run-in water. 
There are significant variations of the style of yield, failure and collapse in some particular geologic settings. Those that have been identified include: flat-dipping sediments or metasediments, of which coal and coal measures are a particular case, ultramafic units, with particular mineralogy, hydrothermally altered rock, typically associated with porphyry copper-gold orebodies or epithermal gold-silver orebodies. Regardless, an extensional mechanism underlies any yield, failure or collapse.

\subsubsection{Sliding/shear mechanisms}

The evidence that supports an extensional mechanism of yield failure and collapse also does not support sliding/shear mechanisms. Likewise, the evidence does not support shallow toppling mechanisms. Basically all the characteristics of an extensional mechanism, above, are inconsistent with 'text-book' shear/sliding mechanisms. Critically, measured and observed displacements do not support a shear/sliding mechanism. Failure does not occur on a single failure surface or narrow zone. Failure does not occur as rigid blocks of rock, failure does not occur instantaneously everywhere in the rock mass, gravity is not the only nor the most significant motive force driving failures.

Analyses based on a sliding model, whether by limit equilibrium or numerical, are likely to be unreliable.

\section{References}

Baczynski, N.R.P., Sheppard, I.K., Smith, K.J., Simbina, P. and Sakail, R. (2008) Toppling slope failure - Predicted versus actual, Ok Tedi, Papua New Guinea, in Proceedings First Southern Hemisphere International Rock Mechanics Symposium (SHIRMS), Y. Potvin, J. Carter, A. Dyskin and R. Jeffrey (eds), Vol. 1 - Mining and Civil, 16-19 September 2008, Perth, Western Australia, Australian Centre for Geomechanics, Perth, pp. 419-431.

Baczynski, N.R.P. (2010) Deformation rebound in a blast-damaged cutback rock slope, in Rock mechanics in civil and environmental engineering, J. Zhao, V. Labiouse, J.P. Dudt and J.F. Mathier (eds), CRC Press, pp. 605-608.

Becker, G.F. (1916) Mechanics of the Panama Canal slides, in Shorter Contributions to General Geology, D. White (ed) Washington Government Printing Office, USGS Numbered Series 1917, Vol. 98, pp. 253-261.

Blackwell, G.H. and Calder, P.N. (1982) Practical aspects of wall stability at Brenda Mines Ltd., Peachland, B.C., in Proceedings Third International Conference on Stability in Surface Mining, C.O. Brawner (ed), 1-3 June 1981, Vancouver, Canada, Society of Mining Engineers, AIME, New York, pp. 573-605.

Bridges, M. (2005) Mechanisms of instability and failure in the walls of open pit mines, Digging Deeper, AMC Consultants, June 2005, pp. 1-4.

Broadbent, C.D. (1972) The practical side of mining research at Kennecott Copper Corporation, in proceedings International Conference on Stability in Open Pit Mining British Columbia University, Centre for Continuing Education, Geotechnical practice for stability in open pit mining, in Proceedings of the second International Conference on stability in open Pit Mining, C.O. Brawner and V. Milligan (eds), 1-2 November, Vancouver, B.C., Canada, Society of Mining Engineers of the American Institute of Mining, Metallurgical, and Petroleum Engineers, New York, 1071 p.

Brummer, R.K., Li, H. and Moss, A. (2006) The transition from open pit to underground mining: an unusual slope failure mechanism at Palabora, in Proceedings International Symposium on Stability of Rock Slopes in Open Pit Mining and Civil Engineering, Cape Town, 3-6 April 2006, The South African Institute of Mining and Metallurgy, pp. 411-420.

Burland, J.B., Longworth, T.I. and Moore, J.F.A. (1977) A study of ground movement and progressive failure caused by a deep excavation in Oxford Clay, Geotechnique, Vol. 27, No. 4, pp. 557-591.

Calder, P.N. and Blackwell, G. (1980) Investigation of a complex rock slope displacement at Brenda Mines, CIM Bulletin, Canadian Institute of Mining, Metallurgy and Petroleum, August 1980, pp. 73-82.

Calderón, A., Catalán, A. and Karzulovic, A. (2003) Management of a 15x106 Tons Slope Failure at Chuquicamata Mine, Chile, in Soil and Rock America 2003 (39th U.S. Rock Mechanics Symposium, Cambridge, Massachusetts, June 2003), P.J. Culligan, H.H. Einstein and A.J. Whittle (eds), Essen: Verlag Glückauf, pp. 2419-2426.

Coates, D.F. (1967) The stability of slopes in open pits, in Proceedings Eighth Commonwealth Mining and Metallurgical Congress, Australia and New Zealand, 1965-1967, R.T. Madigan (ed), Australasian Institute of Mining and Metallurgy, Melbourne, Vol. 6, pp. 543-550.

Coates, D.F. and Yu, Y.S. (1978) Block flow slope instability, CANMET Report 78-10, Canadian Centre for Mineral and Energy Technology.

Coulthard, M.A., Dugan, K.J. and Hutchison, B.J. (1999) Numerical modelling of complex slope movements at Savage River Mine, Tasmania, Mining One Consultants, viewed 29 April 2013, www.miningone.com.au.

Cremeens, J. (2003) Geological controls on complex slope displacement at the pitch reclamation project, D.D. Boyer, P.M. Santi and W.P. Rogers (eds), Engineering Geology in Colorado: Contributions, Trends, and Case Histories: AEG Special Publication 15, Colorado Geological Survey Special Publication, Vol. 55, CD-Rom only.

Cremeens, J., Gilbride, L., Cellan, R. and Cox, A. (2000) Numerical simulation of complex slope displacement, in Proceedings 4th North American Rock Mechanics Symposium, Pacific Rocks 2000: Rock Around the Rim, 31 July-3 August 2000. 
Day, A. and Seery, J. (2007) Monitoring of a large wall failure at Tom Price iron ore mine, in Proceedings International Symposium on Rock Slope Stability in Open Pit Mining and Civil Engineering (Slope07), Y. Potvin (ed), 12-14 September 2007, Perth, Australia, Australian Centre for Geomechanics, Perth, pp. 333-340.

Feltus, W.R. (1993) Victorious East failure at Ora Banda - a case study, in Proceedings Geotechnical instrumentation and monitoring in open pit and underground mining, T. Szwedzicki (ed), Kalgoorlie, Western Australia, Rotterdam, Balkema, 21-23 June.

Gloe, C.S., James, J.P. and Barton, C.M. (1971) Geotechnical investigations for slope stability studies in brown coal open cuts, in Proceedings 1st Australian-New Zealand Conference on Geomechanics, Vol. 1, pp. 329-336.

Gloe, C.S., James, J.P. and McKenzie, R.J. (1973) Earth movements resulting from brown coal open cut mining - Latrobe Valley, Victoria, in Proceedings 11th Symposium on Subsidence in Mines, Wollongong, Australia.

Graham, H.L. (1989) Description of a slope failure in the Vanderbijl pit, Thabazimbi, caused by underground mining activities, in Proceedings Rock Slope Stability Symposium, 10 March, South Africa, The Group, South Africa, pp. 22-27.

Grimes, G. and Nowell, R. (1995) Fatal Fall of Highwall Accident, United States Department of Labor Mine Safety and Health Administration, Rocky Mountain District, Metal and Nonmetal Mine Safety and Health, Accident investigation report, Surface Mine Metal, I.D. No. 39-01284 X52.

Hencher, S.R., Liao, Q.H. and Monaghan, B.G. (1996) Modelling slope behaviour for open-pits, Transactions of the Institution of Mining and Metallurgy, Section A: Mining technology, London: The Institution, pp. 37-47.

Hoek, E. (1972) Recent Rock Slope Stability Research at the Royal School of Mines, London, C.O. Brawner and V. Milligin (eds), Geotechnical practice for stability in open pit mining, The American Institute of Mining, Metallurgical, and Petroleum Engineers, Inc., New York, 1972, p. 27.

Hoek, E., Read, J., Karzulovic, A. and Chen, Z.Y. (2000) Rock Slopes in Civil \& Mining Engineering, in Proceedings GeoEng 2000, International Conference on Geotechnical \& Geological Engineering, 19-24 November 2000, Melbourne, Pennsylvania: Technomic Publishing, pp. 643-658.

Hutchison, B., Dugan, K. and Coulthard, M. (2000) Analysis of flexural toppling at Australian Bulk Minerals Savage River Mine, in Proceedings GeoEng 2000, International Conference on Geotechnical \& Geological Engineering, 19-24 November 2000, Melbourne, Pennsylvania: Technomic Publishing.

Joass, G.G. (1993) Stability monitoring on the west wall of the Muja open cut, in Proceedings Geotechnical Instrumentation and Monitoring in Open Pit and Underground Mining, T. Szwedzicki (ed), Kalgoorlie, Western Australia, Balkema, Rotterdam, pp. 283-291.

Kennedy, B.A. and Niermeyer, K.E. (1970) Slope monitoring systems used in the prediction of a major slope failure at the Chuquicamata Mine, Chile, in Planning Open Pit Mines, in Proceedings International Symposium on the theoretical background to the planning of open pit mines with special reference to slope stability, P.W.J. Van Rensburg (ed), Balkema, Cape Town, South Africa, pp. 215-225.

Mallett, C.W. (1982) Sedimentological control of mining conditions in the Permian coal measures of the Bowen Basin, Australia, in Proceedings Third International Conference on Stability in Surface Mining, C.O. Brawner (ed), 1-3 June, Vancouver, Canada, Society of Mining Engineers of the American Institute of Mining, Metallurgical, and Petroleum Engineers, pp. 333-346.

Merrill, R.H. (1968) Bureau contribution to slope angle research at the Kimbley Pit, Ely, Nevada, Transactions of the Society of Mining Engineers, Vol. 241: 4, pp. 513-525.

Miller, V. (1982) The northeast Tripp slide at Kennecott's Nevada Mine division, Stability in Surface Mining, C.O. Brawner (ed), American Institute of Mining, Metallurgical and Petroleum Engineers, New York.

Moss, A., Diachenko, S. and Townsend, P. (2006) Interaction between the block cave and the pit slopes at Palabora Mine, in Proceedings International Symposium on Stability of Rock Slopes in Open Pit Mining and Civil Engineering, Cape Town, 3-6 April 2006, The South African Institute of Mining and Metallurgy, pp. 399-409.

Naismith, W.A. and Wessels, S.D.N. (2005) Management of a major slope failure at Nchanga Open Pit, Chingola, Zambia, The Journal of the South African Institute of Mining and Metallurgy, Vol. 105, pp. 619-626.

National Academy of Sciences (1924) Report of the Committee of the National Academy of Sciences on Panama Canal Slides, Volume 28, Government Printing Office, Washington.

Newcomen, H.W. and Martin, D.C. (1988) Geotechnical assessment of the southeast wall slope failure at Highmont Mine, British Columbia, CIM Bulletin, Canadian Institute of Mining, Metallurgy and Petroleum, Vol. 81:917, pp. 71-76.

Newcomen, H.W. and Shwydiuk, L. (2003) Managing pit slope displacements: Highland Valley Copper's Lornex pit southwest wall, CIM Bulletin, Canadian Institute of Mining, Metallurgy and Petroleum, Vol. 96:1071, pp. 43-48.

Rapiman, M. (1993) Slope stability and rock mechanics analyses Chuquicamata mine, Codelco, Chile, in Innovative Mine Design for the 21st Century, in Proceedings of the International Congress On Mine Design, W.F. Bawden, J.F. Archibald (eds), August 1993, Kingston, Ontario, Canada, Rotterdam, Netherlands, A.A. Balkema, pp. 23-26.

Read, J.R.L. (2003) Risk and accepted practice in open pit mining geomechanics, in Fifth Large Open Pit Conference, November 2003, Kalgoorlie, Australia, Australasian Institute of Mining \& Metallurgy, Publication Series No7/2003, pp. 3-5.

Reid, G. and Stewart, D. (1986) A large scale toppling failure at Afton, in Proceedings International Symposium on Geotechnical Stability in Surface Mining, 6-7 November 1986, Calgary, AB, Canada, A.A. Balkema, Rotterdam, pp. 215-223.

Rose, N.D. and Hungr, O. (2007) Forecasting potential rock slope failure in open pit mines using the inverse-velocity method, International Journal of Rock Mechanics \& Mining Sciences, Vol. 44, pp. 308-320.

Rose, N.D. and Sharon, R.P. (2000) Practical rock slope engineering designs at Barrick Goldstrike, in Proceedings Slope Stability in Surface Mining, W. Hustrulid, M.K. McCarter and D. Van Zyl (eds), SME, Colorado, pp. 213-218. 
Rosengren, K.J. and Krehula, F.J. (1967) Earth movements and batter stability in the Latrobe Valley open cuts, in Proceedings Eighth Commonwealth Mining and Metallurgical Congress, Australia and New Zealand, 1965-1967, R.T. Madigan (ed), Australasian Institute of Mining and Metallurgy, Melbourne, Vol. 6, pp. 573-585.

Sharp, J.C., Lemay, C. and Neville, B. (1987) Observed behaviour of major open pit slopes in weak ultrabasic rocks, in Proceedings 6th International Congress on Rock Mechanics, G. Herget and S. Vongpaisal (eds), 30 August-3 September 1987, Montreal, Canada, A.A. Balkema, Rotterdam, pp. 541-550.

Sharon, R. (2001) Slope Stability and Operational Control at Barrick Goldstrike, in Proceedings Slope Stability in Surface Mining, W.A. Hustrulid, M.K. McCarter and S.J.A. Van Zyl (eds), Society for Mining Metallurgy, Englewood, USA, pp. 219-226.

Simmons, J.V. (2000) New rock mechanics models needed for slope stability in open pit coal mines, in proceedings of the GeoEng 2000, International Conference on Geotechnical \& Geological Engineering, 19-24 November 2000, Melbourne, Technomic Publishing, Pennsylvania.

Stacey, T.R. and Xianbin, Y. (2004) "Extension" in large open pit slopes and possible consequences, in Proceedings Massmin 2004, M.A. Alfaro and A. Karzulovic (eds), 22-25 August 2004, Santiago, Chile, Mineria Chilena, pp. 280-285.

Thompson, P.W. and Cierlitza, S. (1993) Identification of a Slope Failure Over a Year before Final Collapse Using Multiple Monitoring Methods, Geotechnical Instrumentation and Monitoring in Open Pit and Underground Mining, T. Szwedzicki (ed.), A.A. Balkema, Rotterdam, Netherlands, pp. 491-511.

Voight, B. and Kennedy, B.A. (1979) Slope failure of 1967-1969, Chuquicamata Mine, Chile. In Rockslides and Avalanches, B. Voight (ed), Elsevier Scientific Publishing Company, Amsterdam, pp. 595-632.

Wessels, S.D.N. (2009) Monitoring and management of a large open pit failure, Master's thesis, University of Witwatersrand, Johannesburg.

Victorian Government (2008) Mining Warden Yallourn Mine Batter Failure Inquiry, Victorian Government Printer, No 156 Session 2006-2008.

Zavodni, Z.M. and McCarter, M.K. (1977) Main Hill slide zone, Utah Copper Division, in Proceedings Monograph 1 on Rock Mechanics Applications in Mining, 17th US Symposium on Rock Mechanics, 25-27 August 1976, Snow Bird, USA, American Rock Mechanics Association, Virginia, pp. 84-92. 